\title{
ANALISIS KONDISI LINGKUNGAN HIDROLOGI (Studi Kasus Daerah Kos Di Sekitar Universitas PGRI Pelembang)
}

\author{
${ }^{1}$ Heri Setianto dan ${ }^{2}$ Septian Kurnia \\ Program Studi Pendidikan Geografi Universitas PGRI Palembang \\ $(\nabla)$ setianto.heri8@gmail.com ${ }^{1}$
}

\begin{abstract}
ABSTRAK
Penelitian ini bertujuan untuk menganalisis kondisi lingkungan hidrologi daerah kos-kosan disekitar kampus Universitas PGRI Palembang. Penelitian merupakan penelitian deskriptif, yaitu untuk membuat gambaran mengenai kondisi lingkungan hidrologi pada daerah kos di sekitar kampus Universitas PGRI Palembang sehingga dalam penelitian mengandalkan data primer berupa data uji sampel dan data survai. Dari penelitian yang ada dapat disimpulkan bahwa kondisi hidrologi daerah penelitian sebagian besar berada pada kondisi yang kurang baik seperti penggunaan lahan yang sebagian besar berupa bangunan permanen, kondisi drainase yang buruk, kondisi sanitasi yang kurang memadai serta kualitas air yang berada dibawah ambang batas kondisi perairan yang sehat.
\end{abstract}

Kata Kunci: Lingkungan Hidrologi, Daerah Kos

\section{PENDAHULUAN}

Air merupakan kebutuhan yang paling utama bagi setiap mahluk hidup di permukaan bumi baik manusia, hewan, maupun tumbuh-tumbuhan. Setiap kegiatan kehidupan tidak lepas dari kebutuhan akan air, bahkan segala sesuatu yang hidup berasal dari air. Manusia membutuhkan air yang cukup untuk memenuhi kebutuhan pertanian, industri, maupun kebutuhan domestik, termasuk air bersih. Pertambahan jumlah penduduk yang terus menerus terjadi, membutuhkan usaha yang sadar dan terencana agar sumber daya air dapat tersedia secara berkelanjutan (Cholil, 1998).

Air mempunyai peranan yang sangat penting dalam kehidupan manusia. Di suatu sisi, dengan adanya pertumbuhan jumlah penduduk yang tinggi dan kegiatan ekonomi yang semakin pesat, kebutuhan air semakin meningkat, sedangkan disisi lain kuantitas dan kualitasnya semakin menurun (Purnama, 2010).

Masalah utama yang dihadapi oleh sumberdaya air meliputi kuantitas air yang sudah tidak mampu memenuhi kebutuhan manusia yang terus meningkat dan kualitas air untuk keperluan domestik dan non domestic yang semakin menurun. Kegiatan Industri, kegiatan domestik, dan kegiatan lain dapat berdampak negatif terhadap sumberdaya air antara lain menyebabkan penurunan kualitas air. Kondisi ini dapat menimbulkan gangguan, kerusakan, dan bahaya bagi mahluk hidup yang bergantung pada sumberdaya air. Oleh karenanya diperlukan pengelolaan dan perlindungan sumberdaya air secara seksama (Effendi, 2003).

Kualitas air tidak sama antara satu tempat dengan tempat lainnya, tergantung pada faktorfaktor yang berpengaruh terhadap kualitas air di daerah yang bersangkutan. Secara ringkas dapat dijelaskan bahwa ada dua faktor utama yang berpengaruh terhadap kualitas air di suatu daerah, yaitu faktor alami dan faktor buatan. Faktor alami meliputi batuan dan tanah, vegetasi serta iklim, sedangkan faktor buatan meliputi pupuk dan limbah pertanian, insektisida, limbah domestik serta limbah industri. Di samping itu, erosi yang 
terjadi dibagian hulu dapat pula mempengaruhi kualitas air dibagian hilirnya, terutama dalam hal kekeruhan (Purnama, 2010).

Kegiatan pembangunan yang semakin berkembang terutama pada daerah pusat pertumbuhan seperti daerah kampus atau universitas berdampak pada peningkatan jumlah penduduk sehingga terjadi penutupan permukaan tanah, mempersempit daerah resapan air, dan terjadi peningkatan penggunaan sumberdaya alam. Untuk menjaga keseimbangan lingkungan maka perlu pengelolaan sumberdaya alam secara berkesinambungan dan berkelanjutan.

Kampus utama Universitas PGRI Palembang berada di Kelurahan 3 Ulu Kecamatan Plaju Kota Palembang. Keberadaan kampus membawa dampak yang sangat luas terhadap lingkungan yang ada disekitarnya yaitu sebagai salah satu pemicu pertumbuhan kawasan yang sangat kuat. Hal ini dapat dilihat dari pesatnya pertumbuhan pembangunan seperti pemondokan atau kost, pelayanan jasa, serta rumah pribadi. Tingginya pertumbuhan pembangunan secara langsung akan berdampak pada kondisi hidrologi daerah disekitarnya.

\section{METODOLOGI PENELITIAN}

Penelitian yang dilakukan merupakan penelitian deskriptif, yaitu untuk membuat gambaran mengenai kondisi lingkungan hidrologi pada daerah kos-kosan di sekitar Universitas PGRI Palembang sehingga dalam penelitian mengandalkan data primer berupa data uji sampel dan data survai. Uji sampel kualitas air pada lokasi penelitian dan data survai merupakan data yang diperoleh dari hasil survai terhadap kondisi hidrologi seperti sanitasi, kondisi drainase, dan penggunaan lahan yang ada di lokasi penelitian.

Penelitian ini dilakukan di daerah kos- sekitar Universitas PGRI Palembang Kelurahan Plaju Ulu Kecamatan Plaju yang merupakan daerah administrasi Kota Palembang.

\section{HASIL dan PEMBAHASAN}

Penelitian ini dilakukan di daerah sekitar Universitas PGRI Palembang Kelurahan Plaju Ulu Kecamatan Plaju yang merupakan daerah administrasi Kota Palembang. Peta lokasi penelitian dan kondisi hirdrologi disajikan dalam Gambar 1.

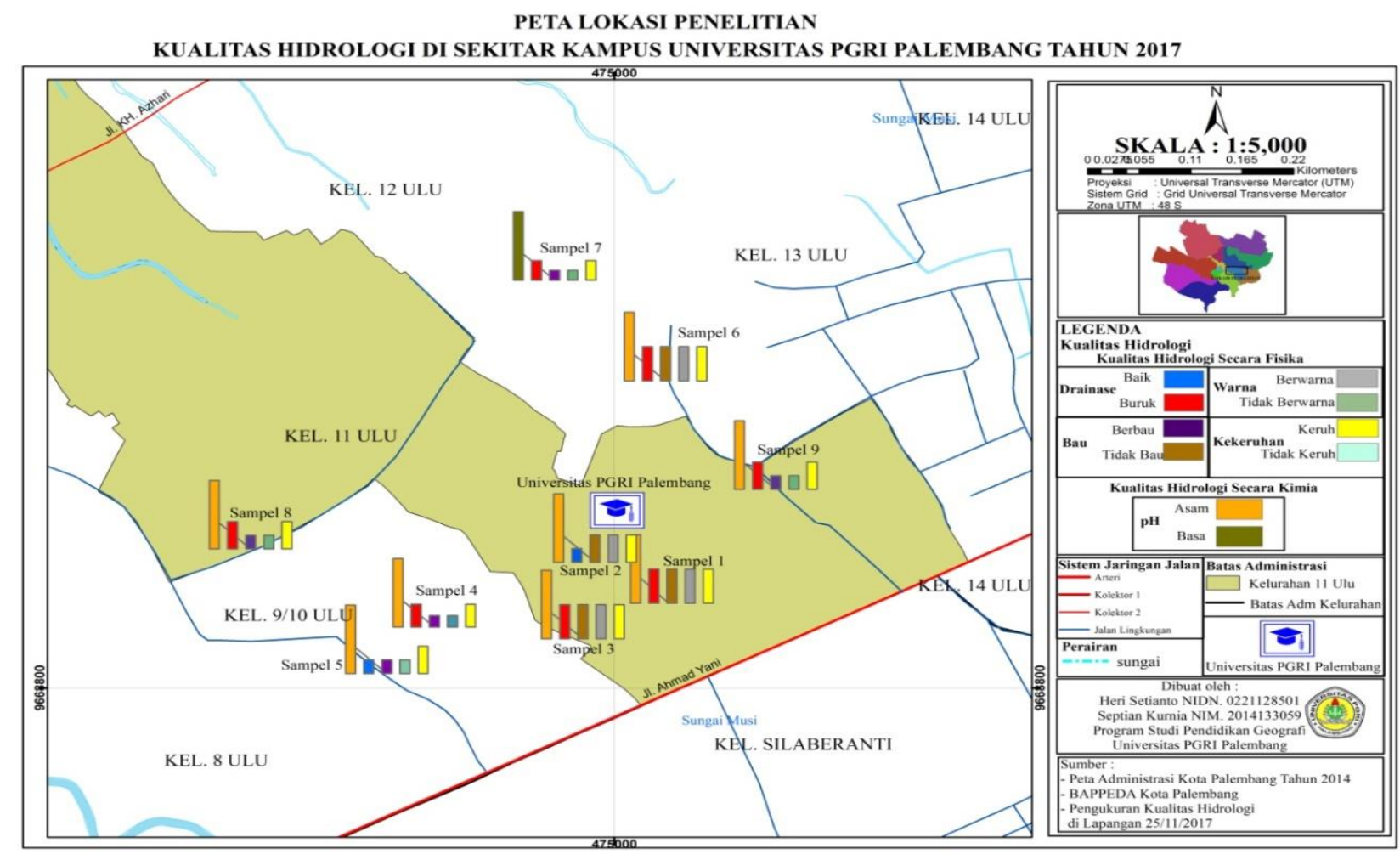

Gambar 1. Peta lokasi penelitian dan kondisi hirdrologi 


\section{Penggunaan Lahan}

Berdasarkan hasil survai dan pengamatan lapangan serta didukung dengan data citra satelit lokasi penelitian dapat disimpulkan bahwa penggunaan lahan pada daerah penelitian sebagian besar diperuntukan sebagai bangunan permanen. Bangunan permanen yang ada diantaranya adalah bangunan rumah sewa atau kos, rumah tinggal, fasilitas umum seperti sekolah dan masjid, serta bangunan-bangunan yang diperuntukan pada sektor jasa seperti toko kebutuhan pokok, fotocopy dan jasa launder. Data penggunaan lahan pada lokasi penelitian disajikan pada Tabel 1 .

Tabel 1. Penggunaan Lahan Daerah Penelitian

\begin{tabular}{cl}
\hline Sampel & \multicolumn{1}{c}{ Penggunaan Lahan } \\
\hline 1 & Pemukian,Jasa, Kos \\
\hline 2 & Pemukian, Jasa, Kos \\
\hline 3 & Pemukiman \\
\hline 4 & Kos \\
\hline 5 & Permukiman \\
\hline 6 & Kos \\
\hline 7 & Pemukiman, Jasa, Kos \\
\hline 8 & Permukiman, Kos \\
\hline 9 & Permukiman, Kos \\
\hline
\end{tabular}

Dari data hasil penelitian pada Tabel 1. Dapat disimpulkan bahwa sebagian besar penggunaan lahan diperuntukan sebagai bangunan permanen.

\section{Kondisi Drainase}

Kondisi drainase pada daerah penelitian sebagian besar pada keadaan yang buruk hal ini dapat dilihat dari kondisi lapangan yang sebagian besar penutup lahan adalah bangunan permanen dan bangunan pengeras yang diperuntukan sebagai penutup seperti pengeras untuk jalan raya, pengeras untuk halaman rumah dan lain sebagainya. Data kondisi drainase daerah penelitian disajikan dalam Tabel 2.

Tabel 2. Kondisi Drainase Daerah Penelitian

\begin{tabular}{cl}
\hline Sampel & \multicolumn{1}{c}{ Kondisi Drainase } \\
\hline 1 & Buruk \\
\hline 2 & Buruk \\
\hline 3 & Buruk \\
\hline 4 & Baik \\
\hline 5 & Buruk \\
\hline 6 & Buruk \\
\hline 7 & Buruk \\
\hline
\end{tabular}

\begin{tabular}{cc}
\hline 8 & Buruk \\
\hline 9 & Buruk \\
\hline
\end{tabular}

\section{Kondisi Sanitasi}

Sanitasi dapat diartikan sebagai suatu usaha pencegahan penyakit yang menitikberatkan pada usaha-usaha secara sadar untuk menjaga kesehatan lingkungan hidup manusia. Dari hasil survai dan pengamatan dilapangan dapat disimpulkan bahwa kondisi sanitasi didaerah penelitian masih pada kondisi kurang baik. Hal ini ditunjukan dengan banyaknya tumpukan sampah illegal yang dibuang oleh masyarakat serta kondisi saluran pembuangan limbah rumahtangga yang belum dikelola dengan baik. Kondisi seperti ini dapat berpengaruh langsung terhadap kesehatan masyarakat yang bermukin disekitarnya. Kondisi sanitasi daerah penelitian disajikan dalam Tabel 3.

Tabel 3. Kondisi Sanitasi Daerah Penelitian

\begin{tabular}{cl}
\hline Sampel & \multicolumn{1}{c}{ Kondisi Sanitasi } \\
\hline 1 & Buruk \\
\hline 2 & Baik \\
\hline 3 & Buruk \\
\hline 4 & Buruk \\
\hline 5 & Baik \\
\hline 6 & Buruk \\
\hline 7 & Baik \\
\hline 8 & Baik \\
\hline 9 & Baik
\end{tabular}

\section{Kualitas pH Air}

Air normal yang menenuhi syarat untuk suatu kehidupan memiliki pH sekitar 6,5-7,5. Air akan bersifat asam atau basa tergantung pada besar dan kecilnya $\mathrm{pH}$. Bila $\mathrm{pH}$ dibawah $\mathrm{pH}$ normal, maka air tersebut akan bersifat asam, sedangkan air yang mempunyai $\mathrm{pH}$ diatas $\mathrm{pH}$ normal maka air akan bersifat basa. Dari hasil uji $\mathrm{pH}$ air pada daerah penelitian dapat dilihat bahwa dari 9 titik uji sampel sebagian besar air memiliki kandungan yang kurang baik yaitu berada pada $\mathrm{pH}$ yang berada dibawah $\mathrm{pH}$ normal yaitu sebanyak 7 titik sampel.

Hal ini dapat disimpulkan bahwa sebagian besar air pada daerah penelitian memiliki $\mathrm{pH}$ yang Asam. Dan hanya dua sampel air yang memiliki kondisi $\mathrm{pH}$ yang netral. Kondisi $\mathrm{pH}$ air pada daerah penelitian dapat dipengaruhi oleh 
kondisi penggunaan lahan yang sebagian besar diperuntukan sebagai permukiman sehingga kegiatan domestik yang ada dapat secara langsung berpengaruh terhadap kualitas lingkungan disekitarnya yang pada akhirnya akan berpengaruh terhadap kualitas air yang ada. Konsentrasi $\mathrm{pH}$ air pada daerah penelitian disajikan dalam Tabel 4.

Tabel 4. Konsentrasi pH Air Daerah Penelitian

\begin{tabular}{cc}
\hline Sampel & Konsentrasi pH \\
\hline 1 & 4 \\
\hline 2 & 5 \\
\hline 3 & 4 \\
\hline 4 & 6 \\
\hline 5 & 5 \\
\hline 6 & 4 \\
\hline 7 & 7 \\
\hline 8 & 5 \\
\hline 9 & 5
\end{tabular}

Dari konsentrasi nilai $\mathrm{pH}$ air pada daerah penelitian dapat sisimpulkan bahwa sebagian besar air berada pada kualitas yang buruk yaitu berada pada konsentrasi $\mathrm{pH}$ yang asam atau berada dibawah $\mathrm{pH}$ normal air pada umumnya.

\section{Warna Air}

Warna air sangat dipengaruhi oleh komposisi dan konsentrasi zat-zat yang terkandung dalam air. Dalam analisis kualitas air terutama airtanah, warna pada air dipengaruhi oleh adanya proses pencucian dari bahan-bahan organik yang terlarut dalam air dan juga disebabkan oleh adanya ganggang atau protozoa, pembuangan limbah dari industri atau rumah tangga (Karmono dan Cahyono,1978). Dari pengertian tersebut dapat diartikan bahwa perubahan warna yang terjadi pada air merupakan hasil dari proses masuk atau dimasukannya zat atau unsure tertentu kedalam air.

Dari hasil survai dan pengamatan yang dilakukan pada daerah penelitian dapat dilihat bahwa sebagian besar sampel air pada daerah penelitian memiliki kondisi air yang berwarna keruh. Tingkat kekeruhan yang ada bervariasi dari tingkat kekeruhan yang sebagian berasal dari sedimen dan kekeruhan yang berasal dari proses mikrobiologi seperti penguraian sampah yang berasal dari sampah domestik. Data kondisi warna air disajikan dalam Tabel 5.

Tabel 5. Kondisi Warna Air Daerah Penelitian

\begin{tabular}{cl}
\hline Sampel & Kondisi Warna Air \\
\hline 1 & Berwarna Keruh \\
\hline 2 & Berwarna Keruh \\
\hline 3 & Berwarna Keruh \\
\hline 4 & Tidak Berwarna \\
\hline 5 & Berwarna Keruh \\
\hline 6 & Berwarna Keruh \\
\hline 7 & Berwarna Keruh \\
\hline 8 & Berwarna Keruh \\
\hline 9 & Berwarna Keruh
\end{tabular}

\section{Bau Air}

Berdasarkan hasil pengamatan di lapangan dari sampel air di daerah penelitian dapat disimpulkan bahwa sebagian besar sampel air yaitu 8 titik sampel memiliki kondisi air yang berbau dan hanya ada satu titik sampel air yang tidak berbau. Konsentrasi bau pada sampel air disebabkan oleh karena adanya unsure kimia dan biologi yang terdapat pada air. Hal ini dapat dilihat dari kondisi air yang telah tercemar baik ileh kegiatan domestic seperti sampah rumah tangga maupun sampah non domestic yang berasal dari sektor jasa yang ada disekitar daerah penelitian.

\section{SIMPULAN}

Perubahan kondisi air sangat dipengaruhi oleh hasil proses kegiatan yang ada didaerah tersebut. Setiap perubahan kondisi perairan merupakan proses masuk atau dimasukannya zat atau organisme oleh hasil kegiatan manusia. Dari penelitian yang ada dapat disimpulkan bahwa kondisi hidrologi daerah penelitian sebagian besar berada pada kondisi yang kurang baik seperti penggunaan lahan yang sebagian besar berupa bangunan permanen, kondisi drainase yang buruk, kondisi sanitasi yang kurang memadai serta kualitas air yang berada dibawah ambang batas kondisi perairan yang sehat. 


\section{DAFTAR PUSTAKA}

Cahyono, Joko dan Karmono. 1978. Pengantar Penentuan Kualitas Air.Yogyakarta

Cholil, M. 1998. Analisis Penurunan Muka Airtanah di Kotamadya Surakarta. Forum Geografi, 12(23).
Effendi, H., 2003. Telaah Kualitas Air Bagi Pengelolaan Sumber Daya dan Lingkungan Perairan. Penerbit Kanisius, Yogyakarta.

Purnama, I.G. 2010. Hidrologi Air Tanah. Penerbit Kanisius,Yogyakarta. 